\title{
Barriers to Derivative Accounting Disclosure: The Case of Vietnamese Firms*
}

\author{
Hanh Thi Hong NGUYEN', Ngoc Minh TRAN², Quyen Le Hoang Thuy To NGUYEN ${ }^{3}$
}

Received: August 01, 2020 Revised: September 06, 2020 Accepted: September 10, 2020

\begin{abstract}
This paper explores the barriers to derivative accounting disclosures in Vietnamese companies and ranks their relative importance for effective and efficient remedies. The Delphi technique was applied to get agreement of panel of experts on the measurement of factors hindering disclosure. Unstructured questionnaires were first sent to twelve experts who had both practical experience and academic knowledge in the field to get ideas on the obstructions to derivatives disclosure. The structured questionnaire was designed to get their agreement on barriers to derivative accounting disclosures. The data analysis with mean, median, mode, standard deviation, and quartile has been implemented to ensure the unanimity. Market-related factors, legislation, accountants' attributes, managers' attributes, information technology and communication, and on-site training were the six major obstacles agreed upon by the experts during their in-depth interviews. Then, these factors were ranked by applying the analytical hierarchy process (AHP). The findings confirmed the priority of information technology and communication, which held the greatest weight. Legislation ranked second, followed by market-related factors and on-site training, which explained the impediments to derivatives disclosure. Managers' and accountants' attributes had the least contribution to the barriers to derivative disclosures. The results have important implications for actions to enhance corporate derivative disclosures in Vietnam.
\end{abstract}

Keywords: Analytical Hierarchy Process, Accounting Management, Derivative Disclosure, Delphi Technique

JEL Classification Code: M41, M49, G39

\section{Introduction}

Derivatives are a means of risk management applied by firms (Hairston \& Brooks, 2019; Lee et al., 2020; Malaquias

\footnotetext{
*Acknowledgements:

The authors are thankful to Ho Chi Minh City Open University for funding this research. We would like to thank the anonymous referees for their helpful comments and suggestions.

${ }^{1}$ First Author. Assistant Professor, Faculty of Accounting and Auditing, Ho Chi Minh City Open University, Vietnam.

Email: hanh.nth@ou.edu.vn

${ }^{2} \mathrm{Ngoc}$ Minh Tran, Lecturer, Faculty of Accounting and Auditing, Ho Chi Minh City Open University, Vietnam. Email: ngoc.tm@ou.edu.vn ${ }^{3}$ Corresponding Author. Assistant Professor, Deputy Director, Office of Cooperation and Research Management, Ho Chi Minh City Open University, Vietnam [Postal Address: 97, Vo Van Tan Street, District 3, Ho Chi Minh City, 724000, Vietnam]

Email: quyen.nlhtt@ou.edu.vn

(c) Copyright: The Author(s)

This is an Open Access article distributed under the terms of the Creative Commons Attribution Non-Commercial License (https://creativecommons.org/licenses/by-nc/4.0/) which permits unrestricted non-commercial use, distribution, and reproduction in any medium, provided the unrestricted non-commercial
original work is properly cited.
}

\& Zambra, 2019; Nguyen \& Faff, 2003). They are used in foreign exchange, interest rate, and commodity markets (Brahmasrene \& Lee, 2020; Lee \& Brahmasrene, 2019). Four main tools have been applied, including (i) forward contracts, (ii) future contracts, (iii) option contracts, and (iv) swap contracts. In principle, these are the hedging tools used to boost the corporate value (Park \& Park, 2020). However, all businesses that use derivatives' financial instruments must measure these instruments, show that they are understandable, and compare risks when being shown in the financial statements (Abdel-khalik \& Chen, 2015). Multinational companies have applied SFAS 133 to enhance their transparency, to provide information on the actual situation that corresponds to the hedging tools, keep updated when using derivatives, and measuring them at fair value in the reports (Park \& Park, 2020; Wang et al., 2005).

Corporate derivatives disclosure can cause equity prices to change the stock market (Bourveau et al., 2018). Fernando et al. (2020) provided empirical evidence on public reactions to the derivatives positions of the gold-mining companies in a survey of 112 firms in this industry. Public notice of an increase in a derivatives position led to a decrease in equity 
prices for a company and its industry. In Vietnam, derivative instruments have been implemented by the companies that have an enhanced investment opportunity, but low levels of cash (Xuan, 2017). Therefore, derivatives are "double-sided" tools. Serious consequences with involved state holders can arise if the disclosure for each financial instrument has not been timely and thoroughly made. Though research has identified the factors driving derivative use, asymmetric information has been the main barrier to their market development. This paper explores the key barriers to derivatives disclosure at companies in Vietnam using both qualitative and quantitative methods.

\section{Literature Review}

The nature of disclosure is to provide an information system for optimal economic decisions that will contribute to social sustainability (Einhorn, 2005; Maj, 2018). Therefore, it is a tangible product featuring both price and quality, which can be significantly impacted by information asymmetry. As a consequence, the market encounters various risks and difficulties in assessing its quality. Besides, how the derivatives are traded is also an influence. In short, a close relationship between the market and information disclosure can be identified (Situ \& Tilt, 2018). A market with perfect information on price, quality, origin, etc., benefits businesses. The same philosophy can be applied to derivatives disclosure.

Risk information disclosures can help reduce asymmetric information about the damage caused by systematic risk. It is a forward-looking behavior and completely different from accounting information in financial statements. However, companies often have not been motivated to comply with risk disclosure (Adam-Müller \& Erkens, 2020). Legislation is a tool to boost the transparency of the information (Casadesús de Mingo \& Cerrillo-i-Martínez, 2018). Legal factors also affect disclosure requirements through the establishment, issuance, and implementation of accounting standards. The legal effect occurs when there is a change in regulationissuing bodies. It means that legislation can target the goals in compliance with economic and social policies. Elshandidy et al. (2013) provided empirical evidence of the significant difference between voluntary and mandatory disclosure. Their research findings support the role of legislation in the public notice of risk information.

Risk disclosure and derivative financial instruments are complicated (Lins et al., 2011; Linsley \& Shrives, 2006). They are subjective and difficult to verify externally. Therefore, management decisions, especially those who are empowered to make decisions about strategic options and resource allocations toward the achievement of the corporate goals, are discretionary (Buckley \& Carter, 2002). In an enterprise, manager, an economic and operation decision-maker, is an integral part of the accounting body. Hence, accountants must be governed and supervised through regulation rather than by the manager's discretion in accounting and financial statement reports (Davis et al., 1982). Accounting principles and accounting standards are formed in the process of market operation (Watts, 2006). As a result, accounting is largely influenced by human factors. Upper echelons theory points out that expertise, experience, and cognition govern the manager's selection of strategy, organization, implementation, economic decision making, and information provision (Hambrick \& Mason, 1984). The manager decides the information disclosure strategy because he or she has the "power" to choose to use either an official or informal notice. A hesitation may stem from the selection of a safe position. Moreover, the usefulness of information disclosure has not been recognized fully. In summary, a manager's attributes can predict disclosure behavior.

In the field of accounting, how to set up regulations has been difficult, and its application has been even harder (Sunder, 2010). Enterprises must comply with mandatory accounting regulations, but they are allowed to select the policies that are to their utmost benefit (Tinker, 1984). Corporate accounting is characterized by accountants'attributes. Changes in the economic and legal environment that pose a risk for the company can be reflected in financial statements through the awareness and expertise of accounting practitioners (Nguyen \& Nguyen, 2020; Sy et al., 2017). Several constraints can be encountered by accountants such as professional regulations, pressure from management decisions and operation, the information collection, processing, and presentation. To ensure fairness among the stakeholders, accountants' full knowledge, indepth expertise, and up-to-date transactions are required as they directly impact the accounting disclosure. Enterprises can take advantage of available resources and integrate internal information related to business activities to develop an information system with the contributions of accountants and managers, creating communication information sources (Williams, 2004). However, given a constantly changing market and a dynamic environment, cross-functional, reliable, and useful information is demanded (EasterbySmith \& Prieto, 2008; Whisenant et al., 2003).

Sutton and Arnold (2013) stated that there is an association between information technology, communications, and accounting. The implementation of transparent accounting information has a positive impact on the economic cycle. Thus, the objective of financial statement disclosure is financial stability. Accounting is required as a neutral technology that functions to reduce information asymmetry and provides necessary transparency for the efficient operation of capital markets. An appropriate information technology system is a prerequisite for businesses to disclose and receive information. Accounting information systems 
are useful in processing information quickly and adapting to the speed, frequency, back-up, and information transmission (Geerts, 2011; Worrell et al., 2013). Accounting software has to ensure timely updating of regulations and meeting (Baxter \& Thibodeau, 2011). Accounting for derivative financial instruments is a huge job requiring quick, accurate, reliable, and timely reports on tracking and recording information on the fair value of assets and liabilities at the end of the period. Thus, an enterprise with an accurate and reliable information system, appropriate information technology, a good reception, and communication are factors that make accounting information convenient and useful.

Knowledge has long been a topic of human resources management (Hattrup et al., 1992). Companies need to focus on providing additional training for their personnel (Gephart et al., 1996). Learning starts at an individual level and is subject to the social contexts and organizational culture (Elkjaer \& Wahlgren, 2005). The individual training of knowledge and expertise of the firm needs to be implemented so it is shared and spread over time (Perez Lopez et al., 2005). The same principle is applied in accounting. The quality of accounting information disclosure is improved with training activities (Li et al., 2018). Uncertainty theory has shown that various contexts require different levels of processing. Financial markets, especially derivative instruments, have always been dynamic and had updated and revised standards (Zeng, 2014). Therefore, on-site training has a direct impact on accounting information disclosures.

\section{Research Methodology}

A mixed method using both qualitative and quantitative research methods was applied in this study. The primary objective has been to explore the barriers to derivatives accounting in the Vietnamese context. First, the literature review together with an in-depth interview of 12 experts in the field using the Delphi technique was conducted to get the agreement on the top key barriers to derivative accounting disclosure at Vietnamese companies (see table 1). Because this technique helped to prevent confrontation or conflicts of personalities and the influence of an influential person in the group of experts (de Jesus et al., 2019; Kembro et al., 2017). Then, the analytic hierarchy process (AHP) is a method of multi-criteria decision analysis that ranked these main factors using pair-based comparisons made by experts (Nguyen \& Nguyen, 2020). According to the theorists, complex relationships can always be analyzed by selecting pairs of components and relating them through their properties. The comparison point is from 1 to 9 with 2 , $4,6,8$ as intermediate levels. Although it is not necessary to use a scale of 1 to 9 for qualitative data, this scale is recommended to quantify the intensity of preference of one component over another, creating a hierarchy between the components (Nguyen et al., 2019). The result of pairing is to input data for calculating the weight of the scale through the AHP algorithm with the following steps: (i) prepare a standardized matrix and; and (ii) calculate the priority vector of each factor and evaluate the consistency ratio (CR) of expert opinion (Huynh et al., 2018; Phong et al., 2017). Inconsistency is acceptable if it does not exceed 0.1 (Saaty \& Vargas, 2012).

Table 1: Top key barriers to derivative accounting disclosures

\begin{tabular}{|c|c|}
\hline Code & Barriers to derivative accounting disclosures \\
\hline C1 & Market-related factors \\
\hline C11 & $\begin{array}{l}\text { The market has not established measurement for } \\
\text { commodity derivatives quality. }\end{array}$ \\
\hline C12 & $\begin{array}{l}\text { The market is at risk in assessing the derivatives } \\
\text { quality }\end{array}$ \\
\hline C13 & $\begin{array}{l}\text { The market lacks supervision on the traded } \\
\text { derivatives }\end{array}$ \\
\hline C14 & $\begin{array}{l}\text { The market is volatile because businesses } \\
\text { change the way of derivatives use }\end{array}$ \\
\hline C15 & $\begin{array}{l}\text { The market has not assessed the performance of } \\
\text { derivatives }\end{array}$ \\
\hline C16 & $\begin{array}{l}\text { The risk level of the market for derivatives has not } \\
\text { been assessed }\end{array}$ \\
\hline $\mathrm{C} 2$ & Legislation \\
\hline $\mathrm{C} 21$ & $\begin{array}{l}\text { Derivative accounting disclosure policies are } \\
\text { insufficient }\end{array}$ \\
\hline $\mathrm{C} 22$ & $\begin{array}{l}\text { The legal system on derivative accounting } \\
\text { disclosure is not complete, comprehensive, and } \\
\text { consistent }\end{array}$ \\
\hline $\mathrm{C} 23$ & $\begin{array}{l}\text { The general legal system on disclosure leads to } \\
\text { unreliability and non-transparency }\end{array}$ \\
\hline $\mathrm{C} 24$ & $\begin{array}{l}\text { The legal documents have not been useful for } \\
\text { accountants in analyzing the risks associated with } \\
\text { derivatives }\end{array}$ \\
\hline $\mathrm{C} 25$ & $\begin{array}{l}\text { The legal documents have not been useful for } \\
\text { accountants in assessing the risks associated } \\
\text { with derivatives }\end{array}$ \\
\hline C3 & Accountants attributes \\
\hline C31 & Derivative accounting presentation limitation \\
\hline
\end{tabular}




\begin{tabular}{|c|c|}
\hline C32 & $\begin{array}{l}\text { Limitation on derivative accounting methods and } \\
\text { principles }\end{array}$ \\
\hline C33 & $\begin{array}{l}\text { Limitation of derivative accounting disclosure } \\
\text { professionality }\end{array}$ \\
\hline C34 & $\begin{array}{l}\text { Lack of ability to update the regulations on } \\
\text { derivatives accounting }\end{array}$ \\
\hline C35 & $\begin{array}{l}\text { There are no plans to improve the } \\
\text { professionalism of derivative accounting }\end{array}$ \\
\hline $\mathrm{C} 4$ & Managers' attributes \\
\hline C41 & $\begin{array}{l}\text { Derivatives use and disclosure have not been } \\
\text { targeted }\end{array}$ \\
\hline C42 & $\begin{array}{l}\text { Cooperation with accountants in derivative } \\
\text { accounting and disclosure has not been made }\end{array}$ \\
\hline C43 & $\begin{array}{l}\text { The importance of derivative accounting and } \\
\text { disclosure has not been recognized }\end{array}$ \\
\hline C44 & $\begin{array}{l}\text { The value of derivative accounting disclosure to } \\
\text { other markets has not been recognized }\end{array}$ \\
\hline C45 & $\begin{array}{l}\text { The improvement of reliability and transparency } \\
\text { resulting from derivative accounting disclosure } \\
\text { has not been recognized }\end{array}$ \\
\hline C5 & Information technology and communication \\
\hline C51 & $\begin{array}{l}\text { Lack of information on the effectiveness of using } \\
\text { derivatives as hedging tools }\end{array}$ \\
\hline C52 & $\begin{array}{l}\text { Lack of information on the complexity of hedging } \\
\text { information }\end{array}$ \\
\hline C53 & $\begin{array}{l}\text { Lack of technical innovation and information } \\
\text { technology system for disclosure }\end{array}$ \\
\hline C54 & Lack of pricing information (input and output) \\
\hline C55 & $\begin{array}{l}\text { Information system does not match the demands } \\
\text { of the accounting system }\end{array}$ \\
\hline C56 & $\begin{array}{l}\text { Lack of an integrated information system (internal } \\
\text { or external system) }\end{array}$ \\
\hline C57 & $\begin{array}{l}\text { The unavailability of an accounting supervision } \\
\text { system }\end{array}$ \\
\hline C6 & On-site training \\
\hline C61 & $\begin{array}{l}\text { There is no training program to update knowledge } \\
\text { for accountants and managers }\end{array}$ \\
\hline C62 & $\begin{array}{l}\text { There is no policy to enhance knowledge of the } \\
\text { current accountants and managers }\end{array}$ \\
\hline C63 & $\begin{array}{l}\text { There is no policy to improve professionality for } \\
\text { accountants and managers }\end{array}$ \\
\hline
\end{tabular}

\section{Results and Discussion}

The Delphi technique was applied to get the experts' agreement on the barriers to corporate derivative accounting disclosures in the Vietnamese context. Six factors, including (i) market-related factors, (ii) legislation, (iii) accountants' attributes, (iv) managers' attributes, (v) information technology and communications, and (vi) on-site training were widely supported during the in-depth interview as well as in the literature review. AHP is then applied to rank the importance of the six factors so that priority remedies can be suggested to aim at the symmetric market. The result in Table 2 shows that information technology and communications share the highest weight. It is assumed that it is even more crucial in complex derivative contracts. However, Vietnam has not developed an information center for market transactions at the macro level. Therefore, traders have not had the opportunity and conditions to grasp the information. The consequence has been the lack of information disclosures about derivative uses, changes, and effectiveness. Also, the shortage of technical innovation, the input, and output pricing system may impede the smooth operation of information disclosure.

By employing an institutional approach, legislation was investigated. The findings were consistent with our argument on the role as the second priority to boost the firm derivatives accounting disclosure. Institutional differences also impact on corporate risk management practices and derivatives use (Bodnar et al., 2003). In our research, two issues of legislation were emphasized. Firstly, an accounting policy that provided direct details and specific guidance on the disclosure and presentation for derivatives accounting was still modest. Secondly, an incomplete legal system with general regulations on information disclosure was available. This causes unreliable information and the firm failure to analyze and evaluate the risks.

Moreover, our research findings also suggested the role of market-related factors and on-site training. The Vietnamese market has not established a quality measurement of traded derivatives and has faced many risks in attempting to assess their quality. Besides, most firms do not have a training program to update knowledge or policies for their managers or accountants (Devanney, 2009; Nguyen \& Ngo, 2020; Pham et al., 2019). Accordingly, their attributes hamper information disclosure. During the interview, we found that the accountants in many firms had limited qualifications. They did not have sufficient expertise, which led to a bad presentation and disclosure of information. Managers were not in a position to fully understanding risk management. The consequence was unclear plans and the absence of prevention goals (Long et al., 2019; Purwanti et al., 2020; Sy et al., 2017). They were not ready to coordinate with accountants in their information presentations and disclosures. 
Table 2: Weight coefficients of barriers to derivative accounting disclosures

\begin{tabular}{|c|c|c|c|}
\hline Goal & Weight & Attribute & Rank \\
\hline \multirow{6}{*}{ Market-related factor } & \multirow{6}{*}{0.257} & $\begin{array}{l}\text { The market has not established measurement for commodity derivatives } \\
\text { quality. }\end{array}$ & 6 \\
\hline & & The market is at risk in assessing the derivatives quality & 5 \\
\hline & & The market lacks supervision on the traded derivatives & 1 \\
\hline & & The market is volatile because businesses change the way of derivatives use & 3 \\
\hline & & The market has not assessed the performance of derivatives & 2 \\
\hline & & The risk level of the market for derivatives has not been assessed & 4 \\
\hline \multirow{5}{*}{ Legislation } & \multirow{5}{*}{0.496} & Derivative accounting disclosure policies are insufficient & 2 \\
\hline & & $\begin{array}{l}\text { The legal system on derivative accounting disclosure is not complete, } \\
\text { comprehensive, and consistent }\end{array}$ & 5 \\
\hline & & $\begin{array}{l}\text { The general legal system on disclosure leads to unreliability and non- } \\
\text { transparency }\end{array}$ & 4 \\
\hline & & $\begin{array}{l}\text { The legal documents have not been useful for accountants in analyzing the } \\
\text { risks associated with derivatives }\end{array}$ & 3 \\
\hline & & $\begin{array}{l}\text { The legal documents have not been useful for accountants in assessing the } \\
\text { risks associated with derivatives }\end{array}$ & 1 \\
\hline \multirow{5}{*}{$\begin{array}{l}\text { Accountants' } \\
\text { attributes }\end{array}$} & \multirow{5}{*}{0.107} & Derivative accounting presentation limitation & 5 \\
\hline & & Limitation on derivative accounting methods and principles & 2 \\
\hline & & Limitation of derivative accounting disclosure professionality & 1 \\
\hline & & Lack of ability to update the regulations on derivatives accounting & 3 \\
\hline & & There are no plans to improve the professionalism of derivative accounting & 4 \\
\hline \multirow{5}{*}{ Managers' attributes } & \multirow{5}{*}{0.138} & Derivatives use and disclosure have not been targeted & 3 \\
\hline & & $\begin{array}{l}\text { Cooperation with accountants in derivative accounting and disclosure has not } \\
\text { been made }\end{array}$ & 4 \\
\hline & & $\begin{array}{l}\text { The importance of derivative accounting and disclosure has not been } \\
\text { recognized }\end{array}$ & 2 \\
\hline & & $\begin{array}{l}\text { The value of derivative accounting disclosure to other markets has not been } \\
\text { recognized }\end{array}$ & 1 \\
\hline & & $\begin{array}{l}\text { The improvement of reliability and transparency resulting from derivative } \\
\text { accounting disclosure has not been recognized }\end{array}$ & 5 \\
\hline \multirow{7}{*}{$\begin{array}{l}\text { Information } \\
\text { technology and } \\
\text { communication }\end{array}$} & \multirow{7}{*}{0.577} & Lack of information on the effectiveness of using derivatives as hedging tools & 5 \\
\hline & & Lack of information on the complexity of hedging information & 7 \\
\hline & & Lack of technical innovation and information technology system for disclosure & 4 \\
\hline & & Lack of pricing information (input and output) & 3 \\
\hline & & Information system does not match the demands of the accounting system & 6 \\
\hline & & Lack of an integrated information system (internal or external system) & 1 \\
\hline & & The unavailability of an accounting supervision system & 2 \\
\hline \multirow{3}{*}{ On-site training } & \multirow{3}{*}{0.207} & $\begin{array}{l}\text { There is no training program to update knowledge for accountants and } \\
\text { managers }\end{array}$ & 1 \\
\hline & & $\begin{array}{l}\text { There is no policy to enhance knowledge of the current accountants and } \\
\text { managers }\end{array}$ & 3 \\
\hline & & There is no policy to improve professionality for accountants and managers & 2 \\
\hline
\end{tabular}




\section{Conclusions}

In recent years, Vietnam is become one of the emerging markets with moderate economic growth (Ha \& Ngoc, 2020; Vo et al., 2020; Nguyen \& Ngoc, 2020; Nguyen \& Nguyen, 2020). This growth is due to the success of the accounting and auditing activities in companies, especially derivative accounting tools for risk management. This study used the integration of both qualitative and quantitative methods with Delphi and AHP techniques in data analysis to explore the factors that hinder the firms' derivative accounting disclosures in the Vietnamese context. The model allowed the assessment based on diversified criteria, while limiting the subjectivity of human beings. The research findings confirmed the priority of information technology and communications, especially in industry 4.0. Immature systems limit the use of derivatives, accounting, and disclosures as a vicious circle.

\section{References}

Abdel-khalik, A. R., \& Chen, P. C. (2015). Growth in financial derivatives: The public policy and accounting incentives. Journal of Accounting and Public Policy, 34(3), 291-318. https://doi.org/10.1016/j.jaccpubpol.2015.01.002

Adam-Müller, A. F., \& Erkens, M. H. (2020). Risk disclosure noncompliance. Journal of Accounting and Public Policy, 39(3), 106739.

Baxter, R. J., \& Thibodeau, J. C. (2011). Does the use of intelligent learning and assessment software enhance the acquisition of financial accounting knowledge? Issues in Accounting Education, 26(4), 647-656. https://doi.org/10.2308/iace-50052

Bodnar, G. M., de Jong, A., \& Macrae, V. (2003). The Impact of Institutional Differences on Derivatives Usage: A Comparative Study of US and Dutch Firms. European Financial Management, 9(3), 271-297. https://doi.org/10.1111/1468-036X.00221

Bourveau, T., Lou, Y., \& Wang, R. (2018). Shareholder Litigation and Corporate Disclosure: Evidence from Derivative Lawsuits. Journal of Accounting Research, 56(3), 797-842. https://doi. org/10.1111/1475-679X.12191

Brahmasrene, T., \& Lee, J. W. (2020). Exchange rate movements and structural break on China FDI inflows. Contemporary Economics, 14(2), 112-126. https://doi.org/10.5709/ce.18979254.335

Buckley, P. J., \& Carter, M. J. (2002). Process and structure in knowledge management practices of British and US multinational enterprises. Journal of International Management, 8(1), 29-48. https://doi.org/10.1016/S10754253(01)00051-5

Casadesús de Mingo, A., \& Cerrillo-i-Martínez, A. (2018). Improving records management to promote transparency and prevent corruption. International Journal of Information
Management, 38(1), 256-261. https://doi.org/10.1016/j. ijinfomgt.2017.09.005

Davis, S. W., Menon, K., \& Morgan, G. (1982). The images that have shaped accounting theory. Accounting, Organizations and Society, 7(4), 307-318. https://doi.org/10.1016/03613682(82)90007-1

de Jesus, A., Antunes, P., Santos, R., \& Mendonça, S. (2019). Eco-innovation pathways to a circular economy: Envisioning priorities through a Delphi approach. Journal of Cleaner Production, 228, 1494-1513. https://doi.org/10.1016/j. jclepro.2019.04.049

Devanney, C. (2009). Realistic expectations: Accounting for young people's progress in training programmes. International Journal of Public Sector Management, 22(1), 8-20. https://doi. org/10.1108/09513550910922360

Easterby-Smith, M., \& Prieto, I. M. (2008). Dynamic capabilities and knowledge management: an integrative role for learning? British Journal of Management, 19(3), 235-249.

Einhorn, E. (2005). The nature of the interaction between mandatory and voluntary disclosures. Journal of Accounting Research, 43(4), 593-621. https://doi.org/10.1111/j.1475679X.2005.00183.x

Elkjaer, B., \& Wahlgren, B. (2005). Organizational learning and workplace learning - Similarities and differences. In: Learning, Working and Living: Mapping the Terrain of Working Life Learning (pp. 15-32).

Elshandidy, T., Fraser, I., \& Hussainey, K. (2013). Aggregated, voluntary, and mandatory risk disclosure incentives: Evidence from UK FTSE all-share companies. International Review of Financial Analysis, 30, 320-333. https://doi.org/10.1016/j. irfa.2013.07.010

Fernando, C. S., Hoelscher, S. A., \& Raman, V. (2020). The informativeness of derivatives use: Evidence from corporate disclosure through public announcements. Journal of Banking and Finance, 114 . https://doi.org/10.1016/j. jbankfin.2019.105731

Geerts, G. L. (2011). A design science research methodology and its application to accounting information systems research. International Journal of Accounting Information Systems, 12(2), 142-151. https://doi.org/10.1016/j.accinf.2011.02.004

Gephart, M. A., Marsick, V. J., Van Buren, M. E., \& Spiro, M. S. (1996). Learning organizations: Come alive. $T$ and $D, 50(12)$, 35-x35.

Ha, N. M., \& Ngoc, B. H. (2020). Revisiting the relationship between energy consumption and economic growth nexus in Vietnam: new evidence by asymmetric ARDL cointegration. Applied Economics Letters, 1-7. https://doi.org/10.1080/13504 851.2020 .1789543

Hairston, S. A., \& Brooks, M. R. (2019). Derivative accounting and financial reporting quality: A review of the literature. Advances in Accounting, 44, 81-94. https://doi.org/10.1016/j. adiac.2018.10.003 
Hambrick, D. C., \& Mason, P. A. (1984). Upper echelons: The organization as a reflection of its top managers. Academy of Management Review, 9(2), 193-206.

Hattrup, K., Schmitt, N., \& Landis, R. S. (1992). Equivalence of Constructs Measured by Job-Specific and Commercially Available Aptitude Tests. Journal of Applied Psychology, 77(3), 298-308. https://doi.org/10.1037/0021-9010.77.3.298

Huynh, V. D. B., Van Nguyen, P., Nguyen, Q. H. T. T., \& Nguyen, P. T. (2018). Application of Fuzzy Analytical Hierarchy Process based on Geometric Mean Method to prioritize social capital network indicators. International Journal of Advanced Computer Science and Applications, 9(12), 182-186. https:// doi.org/10.14569/IJACSA.2018.091227

Kembro, J., Näslund, D., \& Olhager, J. (2017). Information sharing across multiple supply chain tiers: A Delphi study on antecedents. International Journal of Production Economics, 193, 77-86. https://doi.org/10.1016/j.ijpe.2017.06.032

Khoa D. V., Phong T. N., \& Quyen L.H.T.T N. (2020). Disputes in Managing Projects: A Case Study of Construction Industry in Vietnam. Journal of Asian Finance, Economics and Business, 7(8), 635-644. https://doi.org/10.13106/jafeb.2020.vol7.no8.635

Lee, J., Lee, S. J., Choi, S., \& Kim, S. (2020). The usefulness of other comprehensive income for predicting future earnings. Journal of Asian Finance, Economics and Business, 7(5), 3140. https://doi.org/10.13106/jafeb.2020.vol7.no5.031

Lee, J. W., \& Brahmasrene, T. (2019). Long-run and shortrun causality from exchange rates to the Korea composite stock price index. Journal of Asian Finance, Economics and Business, 6(2), 257-267. https://doi.org/10.13106/jafeb.2019. vol6.no2.257

Li, M., Tian, A., Li, S., \& Qi, X. (2018). Evaluating the quality of enterprise environmental accounting information disclosure. Sustainability, 10(7). https://doi.org/10.3390/su10072136

Lins, K. V., Servaes, H., \& Tamayo, A. (2011). Does Fair Value Reporting Affect Risk Management? International Survey Evidence. Financial Management, 40(3), 525-551. https://doi. org/10.1111/j.1755-053X.2011.01152.x

Linsley, P. M., \& Shrives, P. J. (2006). Risk reporting: A study of risk disclosures in the annual reports of UK companies. British Accounting Review, 38(4), 387-404. https://doi.org/10.1016/j. bar.2006.05.002

Long, L. D., Tran, D. H., \& Nguyen, P. T. (2019). Hybrid multiple objective evolutionary algorithms for optimising multi-mode time, cost and risk trade-off problem. International Journal of Computer Applications in Technology, 60(3), 203-214. https:// doi.org/10.1504/IJCAT.2019.100299

Maj, J. (2018). Nature of non-financial information disclosed by Polish organisations. In: Proceedings of the 31st International Business Information Management Association Conference, IBIMA 2018: Innovation Management and Education Excellence through Vision 2020.

Malaquias, R. F., \& Zambra, P. (2019). Complexity in accounting for derivatives: Professional experience, education and gender differences. Accounting Research Journal, 33(1), 108-127. https://doi.org/10.1108/ARJ-11-2017-0192

Nguyen, H., \& Faff, R. (2003). Further Evidence on the Corporate Use of Derivatives in Australia: The Case of Foreign Currency and Interest Rate Instruments. Australian Journal of Management, 28(3), 307-317. https://doi.org/10.1177/031289620302800305

Nguyen, H. M., \& Ngo, T. T. (2020). Psychological capital, organizational commitment and job performance: A case in Vietnam. Journal of Asian Finance, Economics and Business, 7(5), 269-278. doi:10.13106/jafeb.2020.vol7.no5.269

Nguyen, H. M., \& Ngoc, B. H. (2020). Energy consumption Economic growth nexus in vietnam: An ARDL approach with a structural break. Journal of Asian Finance, Economics and Business, 7(1), 101-110. https://doi.org/10.13106/jafeb.2020. vol7.no1.101

Nguyen, P.T, \& Nguyen, C. P. (2020). Risk Management in Engineering and Construction: A Case Study in Design-Build Projects in Vietnam. Engineering, Technology \& Applied Science Research, 10(1), 5237-5241.

Nguyen, P. T., \& Nguyen, Q. L. H. T. T. (2020). Critical Factors Affecting Construction Price Index: An Integrated Fuzzy Logic and Analytical Hierarchy Process. Journal of Asian Finance, Economics and Business, 7(8), 197-204. https://doi. org/10.13106/jafeb.2020.vol7.no8.197

Nguyen, P. T., Vu, N. B., Van Nguyen, L., Le, L. P., \& Vo, K. D. (2019). The Application of Fuzzy Analytic Hierarchy Process (F-AHP) in Engineering Project Management. In: The 2018 IEEE 5th International Conference on Engineering Technologies and Applied Sciences, ICETAS 2018.

Park, H. Y., \& Park, S. Y. (2020). Does hedging with derivatives affect future crash risk? Journal of Asian Finance, Economics and Business, 7(4), 51-58. https://doi.org/10.13106/jafeb.2020. vol7.no4.51

Perez Lopez, S., Montes Peon, J. M., \& Vazquez Ordas, C. J. (2005). Human resource practices, organizational learning and business performance. Human Resource Development International, 8(2), 147-164. https://doi.org/10.1080/13678860500100103

Pham, H. C., Dao, N.-N., Cho, S., Nguyen, P. T., \& Pham-Hang, A.-T. (2019). Construction Hazard Investigation Leveraging Object Anatomization on an Augmented Photoreality Platform. Applied Sciences, 9(21), 4477.

Phong, T. N., Phuc, V. N., \& Quyen, T. T. H. L. N. (2017) Application of fuzzy analytic network process and TOPSIS method for material supplier selection. In: Key Engineering Materials (Vol. 728, pp. 411-415).

Purwanti, A., Titin, Nguyen, Q. L. H. T. T., Mayliza, R., \& Mokodompit, E. A. (2020). Increasing financial performance through effective differentiation strategy, business strategy and strategic change in mediating role of enterprise risk management. International Journal of Innovation, Creativity and Change, 6, 172-190.

Saaty, T. L., \& Vargas, L. G. (2012). Models, methods, concepts \& applications of the analytic hierarchy process (Vol. 175). New York, NY: Springer Science \& Business Media. 
Situ, H., \& Tilt, C. (2018). Mandatory? Voluntary? A Discussion of Corporate Environmental Disclosure Requirements in China. Social and Environmental Accountability Journal, 38(2), 131-144. doi:10.1080/0969160X.2018.1469423

Sunder, S. (2010). Adverse effects of uniform written reporting standards on accounting practice, education, and research. Journal of Accounting and Public Policy, 29(2), 99-114. doi:10.1016/j.jaccpubpol.2009.10.011

Sutton, S. G., \& Arnold, V. (2013). Focus group methods: Using interactive and nominal groups to explore emerging technologydriven phenomena in accounting and information systems. International Journal of Accounting Information Systems, 14(2), 81-88. https://doi.org/10.1016/j.accinf.2011.10.001

Sy, D., Veerasak, L., Tran, T. K., \& Phong, T. N. (2017). Risk assessment for international construction joint ventures in Vietnam. International Journal of Advanced and Applied Sciences, 4(6), 104-114.

Tinker, A. (1984). Theories of the state and the state of accounting: Economic reductionism and political voluntarism in accounting regulation theory. Journal of Accounting and Public Policy, 3(1), 55-74. https://doi.org/10.1016/0278-4254(84)90012-7

Vo, K. D., Nguyen, P. T., \& Nguyen, Q. L. H. T. T. (2020). Disputes in Managing Projects: A Case Study of Construction Industry in Vietnam. Journal of Asian Finance, Economics and Business, 7(8), 635-644. https://doi.org/10.13106/jafeb.2020.vol7. no8.635
Wang, L., Alam, P., \& Makar, S. (2005). The value-relevance of derivative disclosures by commercial banks: A comprehensive study of information content under SFAS Nos. 119 and 133. Review of Quantitative Finance and Accounting, 25(4), 413-427. https://doi.org/10.1007/s11156-005-5462-y

Watts, R. L. (2006). What has the invisible hand achieved? Accounting and Business Research, 36(sup1), 51-61.

Whisenant, J. S., Sankaraguruswamy, S., \& Raghunandan, K. (2003). Market reactions to disclosure of reportable events. Auditing, 22(1), 181-194. https://doi.org/10.2308/aud.2003.22.1.181

Williams, S. M. (2004). An international investigation of associations between societal variables and the amount of disclosure on information technology and communication problems: The case of Y2K. International Journal of Accounting, 39(1), 71-92. https://doi.org/10.1016/j.intacc.2003.12.003

Worrell, J., Wasko, M., \& Johnston, A. (2013). Social network analysis in accounting information systems research. International Journal of Accounting Information Systems, 14(2), 127-137. https://doi.org/10.1016/j.accinf.2011.06.002

Xuan, V. N. (2017). Development of the Vietnam Derivative Stock Market. Asian Journal of Business and Management, 5(3).

Zeng, T. (2014). Derivative financial instruments, tax aggressiveness and firm market value. Journal of Financial Economic Policy, 6(4), 376-390. https://doi.org/10.1108/JFEP-02-2014-0013 